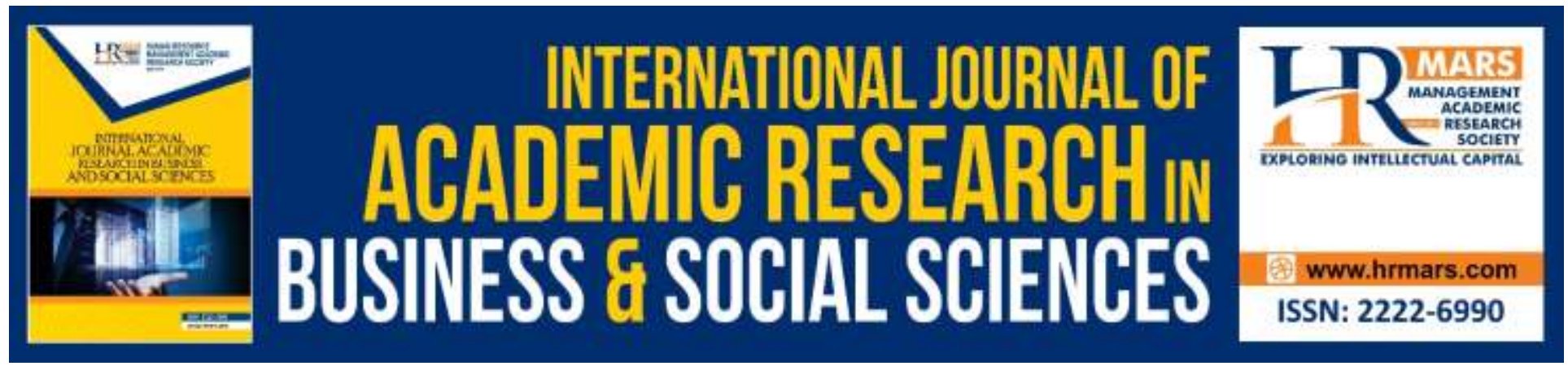

\title{
The Effect of Psychological Empowerment and Job Satisfaction towards Organizational Commitment among Malaysian Employees in Small and Medium Enterprises
}

Lim Lee Ling, Theresa C. F. Ho, Rafidah Othman, Beni Widarman Yus Kelana \& Ong Choon Hee

To Link this Article: http://dx.doi.org/10.6007/IJARBSS/v9-i11/6540

DOI: $10.6007 /$ IJARBSS/v9-i11/6540

Received: 10 October 2019, Revised: 30 October 2019, Accepted: 03 November 2019

Published Online: 19 November 2019

In-Text Citation: (Ling et al, 2019)

To Cite this Article: Ling, L. L., Ho, T. C. F., Othman, R., Kelana, B. W. Y., \& Hee, O. C. (2019). To Investigate the Relationship between Job Demand, Job Resources and Job Performance: An Examination of Mediating Variables. International Journal of Academic Research in Business and Social Sciences, 9(11), 176-184.

Copyright: (c) 2019 The Author(s)

Published by Human Resource Management Academic Research Society (www.hrmars.com)

This article is published under the Creative Commons Attribution (CC BY 4.0) license. Anyone may reproduce, distribute, translate and create derivative works of this article (for both commercial and non-commercial purposes), subject to full attribution to the original publication and authors. The full terms of this license may be seen at: http://creativecommons.org/licences/by/4.0/legalcode

Vol. 9, No. 11, 2019, Pg. 176 - 184

http://hrmars.com/index.php/pages/detail/IJARBSS

JOURNAL HOMEPAGE

Full Terms \& Conditions of access and use can be found at http://hrmars.com/index.php/pages/detail/publication-ethics 


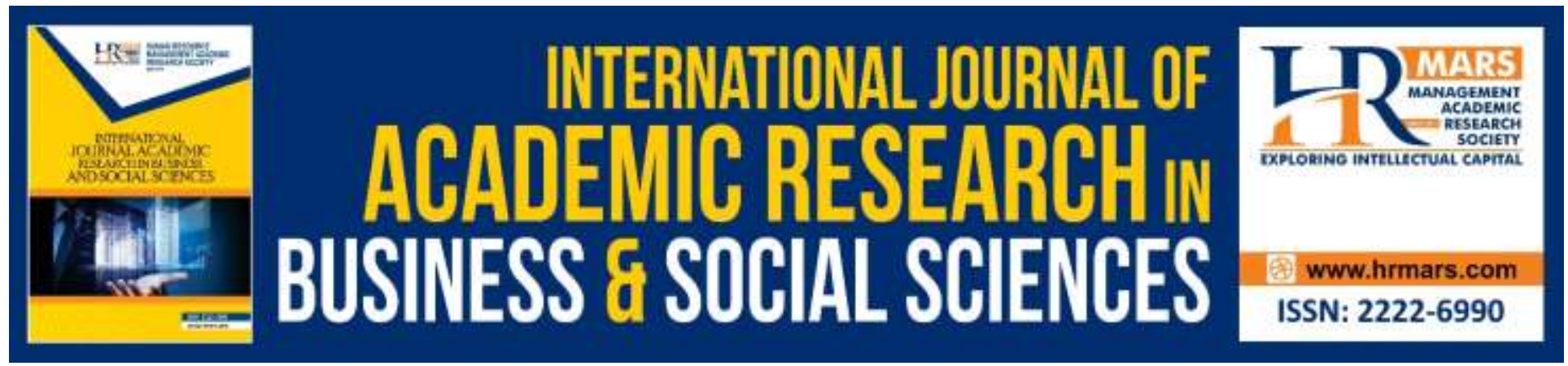

\title{
The Effect of Psychological Empowerment and Job Satisfaction towards Organizational Commitment among Malaysian Employees in Small and Medium Enterprises
}

\author{
Lim Lee Ling, Theresa C. F. Ho, Rafidah Othman, Beni Widarman \\ Yus Kelana \& Ong Choon Hee
}

Azman Hashim International Business School, Universiti Teknologi Malaysia, Malaysia

\begin{abstract}
Employees' organizational commitment towards an organization is crucial as it is one of the factors that will define organizational success. This article aims to study the antecedents of organizational commitment among employees of Small and Medium Enterprises (SMEs) in Malaysia. The antecedents are employees' psychological empowerment and job satisfaction. Hence, the relationships of employees' psychological empowerment and job satisfaction towards the employees' organizational commitment will be examined in this study. This article also studies whether employees' psychological empowerment and job satisfaction will have different impact on each of the three components under Meyer and Allen's Three Components Model. Keywords: Psychological Empowerment, Job Satisfaction, Organizational Commitment, Smalland Medium Enterprises.
\end{abstract}

\section{Introduction}

Small and Medium Enterprises (SMEs) play an important role to promote the economic growth of a country, especially in a developing country like Malaysia. SMEs can be described as one of the crucial economic driving forces in developed or developing countries as SMEs contribute substantially to the total economic growth (Zabri \& Lean, 2014). SMEs contributed 38.3\% of Malaysia's Gross Domestic Product (GDP) in 2018, an increase from $37.8 \%$ in 2017 . SMEs contributed RM521.7 billion versus the county's total GDP of RM1.36 trillion in 2018 due to expansion in the services and manufacturing sectors (Chong, 2019). In addition, SMEs also served as an important source of job opportunities. Given the importance of SMEs to a country's 
growth and survival, it is pertinent that more research needs to be done to ensure the survival of the SMEs.

Current studies have proven that employees are considered to be one of the primary sources of competitive advantage (Davis, 2017; Debarun, 2019), and improving employees' commitment towards the organization is crucial. In the current competitive workplace, employers are constantly looking ways to retain committed employees and improve employees' commitment to the organization due to the rise of employees' turnover rate which incurred high cost to the organization Labatmediene (2007). According to Singh (2013), the cost incurred in relevant to employees' turnover are basically based on their job level and it is generally ranged from $50 \%$ $200 \%$ per employee's annual salary. Thus, it is pertinent to explore the antecedent of employees' commitment towards their organization.

This study utilizes the Social Exchange Theory (SET) as an underpinning theory for the research framework. The notion behind SET is behavioral interactions between individuals will reinforce the other's behavior (Zoller \& Muldoon, 2019; Homans, 1961). Positive interactions between management and employees build trust which will result in beneficial reciprocity in behaviors (Trinchero, Farr-Wharton, \& Brunetto, 2019). In this study, it is postulated that psychological empowerment and job satisfaction will create a positive interaction between management and employees. This in turn will have an impact on employees' commitment towards the organization. Employees' commitment towards the organization can be classified into 3 categories according to the Three Components Model (TCM), developed by Meyer and Allen (1991). The three components comprised affective, continuance and normative components. Several researches showed that affective commitment is the most crucial component as compared to the other two components and was followed by normative commitment, and continuance commitment (Chan 2003; Jha, 2001).

Erdem and Kaya (2013) stated that an individual employee with high organizational commitment will be more productive and loyal to the organization. In view of this reason, employees' organizational commitment has become one of the most important issues to ensure organizational success. Hence, it is essential for organizations to understand the antecedents of organizational commitment of employees to achieve organizational success. In the past, most studies focused on the consequences of organizational commitment i.e. turnover intention, productivity and retention of employees in the context of occupational psychologists and large organization. Some researches revealed a significant relationship between employees' psychological empowerment and job satisfaction towards their organizational commitment. However, most of those researches are based on Western countries or well-known organizations and there seems to be a dearth of researches that were done in the context of SMEs in emerging economies such as Malaysia. Therefore, this paper endeavours to analyze the impact of three types of psychological empowerment and job satisfaction on organizational commitment in relation to affective, continuance and normative commitment in the context of SMEs. 
INTERNATIONAL JOURNAL OF ACADEMIC RESEARCH IN BUSINESS AND SOCIAL SCIENCES

Vol. 9, No. 11, November, 2019, E-ISSN: 2222-6990 @ 2019 HRMARS

\section{Literature Review and Preposition Development}

In this section, discusses on the definitions and concepts of the psychological empowerment, job satisfaction and organizational commitment. This segment will also discuss and develop prepositions based on past literature reviews for this research.

\subsection{Psychological Empowerment}

Employee empowerment is crucial for an organization because it fulfills an individual's need for a sense of control (Jha, 2011). Psychological empowerment can be defined as the motivational construct which includes four dimensions namely, meaningfulness, competence, selfdetermination and impact. (Spreitzer, 1995). According to Spreitzer (1995), meaningfulness refers to the value of work purpose based on the perspective of the individual employee while competence refers to an employee's belief in performing the tasks. Self-determination refers to an individual's sense of having a choice to initiate and regulate his or her action and (Jha, 2011; Spreitzer, 1995). Last but not least, impact is a feeling that an employee's ability to influence the organization's outcomes (Stewart, McNulty, Griffin, \& Fitzpatrick, 2010; Spreitzer \& Doneson, 2005).

\section{Job Satisfaction}

Job Satisfaction can be defined as any psychological, physiological and environmental circumstances that lead an individual to feel pleased in his current position (Hoppock 1935). It also refers to an employees' affectional tendency towards their job where the attitude of an employee will affect the employee's behaviour (Weiss, 2002). Job satisfaction can also be defined as employees' feeling of contentment towards their jobs (Price, 2001).

\section{Organizational Commitment}

The organizational-commitment construct is gaining popularity in different contexts (Rafique, Hameed, \& Agha, 2018). Organizational commitment can be defined as an employee's intensity to recognize and participant in an organization which include willingness to put in considerable effort, definite wishes to stay in the organization and having strong belief to accept the values and goals of the organization according to Porter et al. (1974). On the other hand, O'Reilly and Chatman (1986) defined organizational commitment as the psychological attachment of an employee toward his organization or a psychological bond that link the employees with the organization. According to Meyer and Allen (1991), organizational commitment can be divided into three dimensions comprising affective, continuance and commitment.

\section{Preposition Development}

Many organizations have started to implement empowerment practices in the workplace as one of the initiatives to improve employees' organizational commitment. By improving employees' organizational commitment will improve organizational effectiveness. Research has proven that organizational commitment rises when the perception of empowerment rises (Jha, 2011). Empirical relationship between the two variables is also being proven from past researches in different group of respondents. According to Spreitzer (1995); Meyer and Allen (1991), an 
organization that can provide substantial opportunities for their employees to take more responsibilities will encourage its employees to be more committed to their work even though it is challenging. Marzec (2014) found that psychological empowerment has the strongest correlation with affective and normative commitment but having the weakest correlation toward continuance commitment. This result was further supported by (Jha, 2011). Furthermore, in the study conducted by Ahmad and Oranye (2010) showed that Malaysian nurses who felt more empowered were more committed to the organization. Hence based on the discussion above, this research proposed that:

Preposition 1a: Psychological empowerment has a positive impact on affective commitment Preposition 1b: Psychological empowerment has a positive impact on continuance commitment

Preposition 1c: Psychological empowerment has a positive impact on normative commitment As for the relationship between job satisfaction and organizational commitment, previous researchers found that job satisfaction affects organizational commitment. Researchers such as Ahmad (2018) Moonsri, (2018) and Saridakis (2018) postulated that when employees are truly satisfied with their job, they will be more committed to their organization. Employees who are committed will eventually improve the overall organizational development and ensure the organizational success. Despite there are numerous factors that will affect employees' organizational commitment, it is proven that superiors or colleagues who offered support or showed concern will greatly improve employees' organizational commitment (Joiner \& Bakalis, 2006; Beheshtifar \& Herat, 2013) In addition, researches also proved that when employees are satisfied with their job position or job scope, they will be more committed to their work. Hence, it is crucial for organization to understand the concept and relationship between the two variables. Based on the above discussion, this research proposed that:

Preposition 2a: Job satisfaction has a positive impact on affective commitment Preposition $2 \mathrm{~b}$ : Job satisfaction has a positive impact on continuance commitment Preposition 2c: Job satisfaction has a positive impact on normative commitment

Independent Variable

\section{Psychological Empowerment}

\section{Dependent Variable}

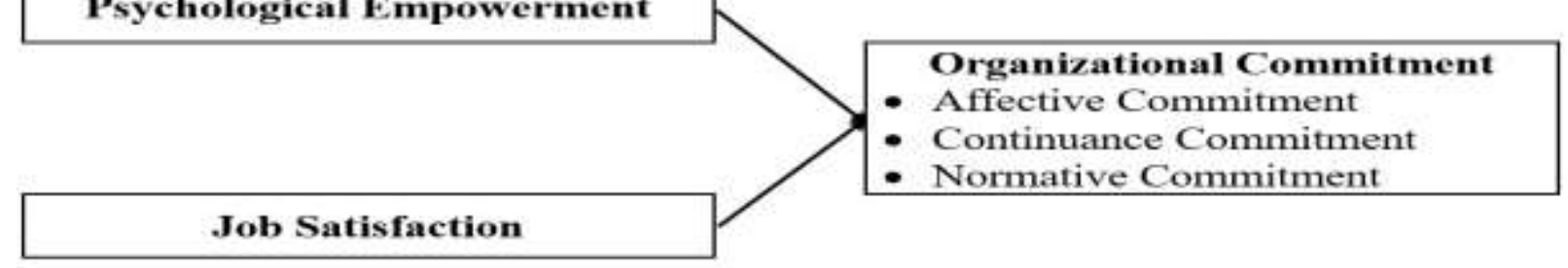

Figure 1: Proposed Research Framework 
Figure 1 depicts the proposed model and the relationships between the variables. In this study, the endogenous variable proposed are Psychological Empowerment and Job Satisfaction. The exogenous variable in this model is Organizational Commitment comprising three dimensions namely, affective commitment, continuance commitment and normative commitment.

\section{Methodology}

\section{Sample and Data Collection}

The targeted population for this study would be employees working in SMEs located in Selangor, Kuala Lumpur, Johor Bahru. These three states were chosen due to the high concentration of Malaysian SMEs in these states (45.3\%) (SME Annual Report 2017/2018). Employees who are not holding any managerial positions will be selected as respondents in this study. Self- administered questionnaires will be the main method of data collection. Prior to receiving the questionnaires, participants will be given a cover letter explaining the purpose and to ensure respondents' confidentiality.

\section{Measures}

In assessing psychological empowerment construct this study will use the 12 items from the multidimension questionnaire developed by Spreitzer (1995). This measurement has four dimensions that are: competence, self-determination, impact and meaning. As for the Job Satisfaction the questionnaire will be adopted from studies done by Jung \& Yoon, (2015). Lastly, the questionnaire for Organizational Commitment will be adopted from Jaros (2007) who improvised the questionnaire developed by Meyer and Allen (1991). The survey instrument that will be used to measure employees' psychological empowerment, job satisfaction and organizational commitment utilizes a seven-point Likert scale ranging from 1 strongly disagree to 7 strongly agree.

\section{Implications \& Research Limitation}

This research has two main objectives. Firstly, this research intends to propose the relationship between psychological empowerment and organizational commitment. The proposed preposition will provide insights for SMEs to encourage psychological empowerment in the workplace. Given the size and flexibility of SMEs in managing their human resources, psychological empowerment could be implemented to enhance organizational commitment among their employees. The second objective is to investigate whether job satisfaction will pose an impact on organizational commitment. The proposed preposition, once being tested empirically would provide support on the importance of monitoring and maintaining employees' job satisfaction. As SMEs faced challenges in recruiting and retaining employees, employees' job satisfaction must not be taken lightly. SMEs need to be aware of the dimensions of job satisfaction such as pay, fringe benefits, promotion, supervision and communication and take initiatives to review and monitor their employees' level of job satisfaction.

In relation to research limitation, this study is only limited to the context of Malaysian SMEs. Furthermore, the author of this article did not carry out any empirical study. Hence, there is no 
empirical evidence to prove the literature review and the content is only based on those results found by previous researches. For future studies, it is highly recommended that researchers conduct empirical studies as the empirical results gathered would be a great contribution to the subject of psychological empowerment, job satisfaction and organizational commitment. Besides that, it is recommended to include other antecedents of organizational commitment.

\section{Conclusion}

This article explores the antecedents of organizational commitment of the employees working in SMEs in Malaysia. In terms of employees' psychological empowerment and job satisfaction, the research framework suggested that psychological empowerment and job satisfaction of employees will affect their commitment towards the organizations, which in turn affects the turnover rate of the organizations. In this study, these two independent variables play an important role in SME organizations as employees' organizational commitment determine the organizational success. Hence, this research provides an insight for Malaysian SMEs on the importance of improving their human resource practices. This would lead to higher job satisfaction and organizational commitment among employees working in Malaysia SMEs.

\section{References}

Ahmad, A. (2018). The relationship among job characteristics organizational commitment and employee turnover intentions. Journal of Work-Applied Management, 10(1), 7492. https://doi.org/10.1108/JWAM-09-2017-0027

Ahmad, N., \& Oranye, N. O. (2010). Empowerment, job satisfaction and organizational commitment: a comparative analysis of nurses working in Malaysia and England. Journal of Nursing Management, 18(5), 582-591.

Beheshtifar, M., \& Herat, B. H. (2013). To promote employee's commitment via perceived organizational support. International Journal of Academic Research in Business and Social Sciences, 3(1), 306-313.

Cavus, M. F., \& Demir, Y. (2010). The impacts of structural and psychological empowerment on burnout: a research on staff nurses in Turkish state hospitals. Canadian Social Science, 6(4), 63-72.

Chan, Y. H. (2003). A nomological network approach to the study of antecedents, moderator, mediators and outcomes of psychological empowerment. The University of Memphis.

Cho, T., \& Faerman, S. R. (2010). An integrative approach to empowerment: construct definition, measurement, and validation. Public Management Review, 12(1), 33-51.

Chong J. H. (2018). Malaysia SME contribution to GDP up at $38.3 \%$ in 2018. The Edge Market https://www.theedgemarkets.com/article/malaysia-sme-contribution-gdp-383-2018 July 312018

Cohen, A. (2007). Commitment before and after: An evaluation and reconceptualization of organizational commitment. Human Resource Management Review, 17(3), 336-354. 23.

Demir, M. C. (2002). Job satisfaction of nurses, working at Turkish Military Forces Hospitals. Military Medicine, 167, 402-404. 16. 
Erdem, B., \& Kaya, I. (2013). Organizational commitment levels of employees working at hotel enterprises: the case of five stars hotels in Marmaris/Mugla, Turkey. International Journal for Human Capital Development, 1(2), 07-21. 28.

Feinstein, A. H. and Vondrasek, D. (2001). A study of relationships between job satisfaction and organizational commitment among restaurant employees. Journal of Hospitality, Tourism \& Leisure Science.

Homans, G. C. (1961), Social Behaviour: Its Elementary Forms, Harcourt, Brace and World, New York, NY

Hoppock, R. (1935). Job Satisfaction., New York, Harper and brothers.

Jha, S. (2011). Influence of psychological empowerment on affective, normative and continuance commitment: a study in the Indian IT industry. Journal of Indian Business Research, 3(4), 263-282.

Joiner, T. A., \& Bakalis, S. (2006). The antecedents of organizational commitment: the case of Australian casual academics. International Journal of Educational Management, 20(6), 439452.

Labatmediene, L., Endriulaitiene, A., \& Gustainiene, L. (2007). Individual correlates of organizational commitment and intention to leave the organization. Baltic Journal of Management, 2(2), 196-212.

Marzec, I. (2014). Using employee empowerment to encourage organizational commitment in the public sector. Journal of Positive Management, 5(2), 43-52.

McShane, S. L., \& Glinow, V. M. A. (2010). Organizational behavior: Emerging knowledge and practice for the real world. (5th ed.). New York: McGraw-Hill/Irwin.

Menon, S. (2001). Employee empowerment: an integrative psychological approach. Applied Psychology, 50(1), 153-180.

Meyer, J. and Allen, N. (1991). A three-component conceptualization of organizational commitment. Human resource management review, 1, 61-89. 21.

Meyer, J. P., \& Herscovitch, L. (2001). Commitment in the workplace: toward a general model. Human Resource Management Review, 11(3), 299-326.

Meyer, J. P., Stanley, D. J., Herscovitch, L. and Topolnytsky, L. (2002). Affective, Continuance, and Normative Commitment to the Organization: A Meta-analysis of Antecedents, Correlates, and Consequences. Journal of Vocational Behavior, 61, 20-52.

Mowday, R. T., Porter, L. W., \& Steers, R. (1982). Organizational linkages: The psychology of commitment, absenteeism, and turnover. New York: Academic Press Inc.

Naqvi, S. A. H., Hashmi, M. A., Raza, S. A., Zeeshan, A., \& Shaikh, F. M. (2011). Impact of supportive leadership and organizational learning culture as a moderator on the relationship of psychological empowerment and organizational commitment. Australian Journal of Business and Management Research, 1(8), 65-71.

O'Reilly, C. A., \& Chatman, J. (1986). Organizational commitment and psychological attachment: the effects of compliance, identification, and internalization on prosocial behavior. Journal of Applied Psychology, 71(3), 492-499. 
INTERNATIONAL JOURNAL OF ACADEMIC RESEARCH IN BUSINESS AND SOCIAL SCIENCES

Vol. 9, No. 11, November, 2019, E-ISSN: 2222-6990 @ 2019 HRMARS

Porter, L., Steers, R., Mowday, R., and Boulian, P. (1974). Organizational commitment, job satisfaction, and turnover among psychiatric technicians. Journal of Applied Psychology, 59, 603-609.

Price, J. L. (2001). Reflections on the determinants of voluntary turnover. International Journal of Manpower, 22, 600-624.

Raquib, M. A., Anantharaman, R. N., Eze, U. C., \& Murad, M. W. (2009). Empowerment practices and performance in Malaysia-an empirical study. International Journal of Business and Management, 5(1), 123-149.

Rawat, P. S. (2011). Workplace Empowerment and commitment: an empirical study. International Journal of Social Science and Humanity, 2(1), 65-69.

Saridakis, G., Lai, Y., Rebeca I. Torres, M., \& Gourlay, S. (2018) Exploring the relationship between job satisfaction and organizational commitment: An instrumental variable approach. The International Journal of Human Resource Management, 1-31 https://10.1080/09585192.2017.1423100

Singh, H. (2013). Talent management: stay interviews. Malaysia Labour Review, 7(2), 41-48. 27.

Spector, P. E. and Fox, S. (2010). Theorizing about the deviant citizen: An attributional explanation of the interplay of organizational citizenship and counterproductive work behavior. Human Resource Management Review, 20, 132-143.

Spreitzer, G. M. (1995). Psychological empowerment in the workplace: dimensions, measurement, and validation. Academy of Management Journal, 38(5), 1442-1465.

Spreitzer, G. M., \& Doneson, D. (2005). Musing on the past a future of employee empowerment forth coming in the handbook of organizational Development (Edited by Tomummings).

Vroom, V. H. and Jago, A. G. (2007). The Role of the Situation in Leadership. American Psychologist, 62, 17-24.

Weiss, H. M. (2002). Deconstructing job satisfaction: Separating evaluations, beliefs and affective experiences. Human Resource Management Review, 12, 173-194.

Wiens, S., Babenko-Mould, Y., \& Iwasiw, C. (2014). Clinical instructors' perceptions of structural and psychological empowerment in academic nursing environments. The Journal of Nursing Education, 53(5), 265-270.

Young-Ritchie, C., Laschinger, H. S., \& Wong, C. (2009). The effects of emotionally intelligent leadership behavior on emergency staff nurses' workplace empowerment and organizational commitment. Nursing Leadership, 22(1), 70-85. 31.

Zabri, S. M., \& Lean, J. (2014). SME Managers' Financing Preferences: The Case of Successful SMEs in Malaysia. In Proceedings of 5th Asia Pacific Business Research Conference (pp. 113). 